\title{
INVESTMENT RISK IN THE CONTEXT OF PRICE CHANGES ON THE REAL ESTATE AND STOCK MARKETS
}

\author{
Rafał Wolski, Ph.D. \\ Faculty of Economics and Sociology \\ University of Lodz \\ e-mail:rwolski@uni.lodz.pl
}

\begin{abstract}
The residential real estate market is thought to show a tendency for wide fluctuations in prices, as a result of which price bubbles appear. This element of risk has a direct bearing on investors interested in speculation and those seeking to meet their housing needs. Wide fluctuations in the values of real estate affect the investors' financial situation in many ways, by determining the possibility of meeting one's housing needs, reducing or sometimes raising creditworthiness, and by increasing investment risk measured by volatility. Omitting the obvious social dimension of the residential real estate market and concentrating on its financial aspects, the author of the article analyses to what degree wide swings in prices can be recognized as specific to this market. To this end, the volatility of prices in the stock market and in the secondary housing market in Poland is compared. An analysis is performed to establish which of them has higher average volatility measures or rates of return, i.e. which of them is more profitable or secure for investors. Statistical tests are used to find out whether average rates of return or measures of risk are equal or different between the two markets. The results of the research show that the secondary housing market and the stock market differ concerning cumulative average rates of return and standard deviations. In the first of them, they are respectively higher and lower.
\end{abstract}

Key words: capital market, real estate market, risk of investments, price changes.

JEL Classification: G11, G12, R31.

Citation: Wolski R., 2016, Investment Risk in the Context of Price Changes on the Real Estate and Stock Markets, Real Estate Management and Valuation, Vol. 24, No. 1, pp. 41-50.

DOI: $10.1515 /$ remav-2016-0004.

\section{Introduction}

Investors may choose from a range of investment options, but their decisions determine future rates of return. The author assumed for the purposes of this article that the obstacles investors face were not a serious problem for them and so they could freely invest their resources. This assumption is unrealistic for most investors, but some of them can certainly afford investments big enough to allow them to ignore various limitations. The focus of this research is on two markets: the stock market and the secondary housing market. Investors can choose between them, but in making choices they must be aware of where the markets are different from each other. The basic difference seems to lie in the maturity of financial instruments quoted on them. Long-term investments are typical of the real estate market, whereas the stock market offers investments of various maturities. They are similar, however, in that long-term investments are possible in both of them. The author decided to analyze the two markets to establish in which of them greater stability of investments could be expected. The level of security was evaluated between the markets in terms of price changes. The research was inspired by the opinions of some researchers, according to whom dynamic changes in prices in the real estate market, especially in the housing market, make it susceptible to price bubbles and, consequently, 
make investment riskier. The question that must be asked in this context is about which of the two markets - the secondary housing market or the dynamic stock market - is safer for investors. The author analyzed prices quoted in both of them and compared their variability by subjecting a range of financial indices to statistical analysis. The hypothesis formulated for the research was that the secondary housing market was a safer alternative.

\section{Stock market vs. secondary housing market}

The real estate market is one of the oldest markets known in the economy, like the labor market and the commodity market. It has been in existence since people started buying and leasing land and homes. While it may not have any physical form and may be merely an intention to make a transaction, the real estate market as we know it today, including the housing market, started to take shape with the economic development of the world. The market and its subtypes evolved in time, providing many opportunities for investment. Two of these subtypes are the buy-to-let market and the capital investment market (KUCHARSKA - STASIAK 2006, pp. 40, 41). Capital investments in real estate are the most important as far as the aim of this article is concerned, because they are made for similar reasons as those guiding certain investors in the capital market. Studies show that the main motivation for making a capital investment in real estate does not necessarily have to be the wish to meet one's housing needs. Which of the above-mentioned types of motivation for investment will predominate can be a matter of individual preferences, and in different regions of the same country one or the other may be given more importance (DUSANSKY et al. 2012). In Poland, too, investment of capital is indicated as a reason for buying a flat, but it is outside of investors' top preferences, or so was the case when concerning the Poznan housing market in the years 2004-2007 (STRĄCZKOWSKI 2009).

The financial market started expanding following the development of money and its increasing importance in the economy. Flows of capital from those who possessed it to those who needed it were directed into formal channels. The division of capital into different classes was acknowledged by the variety of instruments traded in the financial market, starting from currencies, through bank deposits to securities confirming the co-ownership of companies. Investors are usually interested in all segments of the financial market, but those of them who are sensitive to rates of return give special attention to the capital market where financial instruments of long maturity are available. Long maturity is usually understood as one longer than 1 year, but this division is purely arbitrary and only serves the purpose of theoretical clarity (DĘBSKI 2010, pp. 13-23). It is of no special significance to investors. The main criterion that the risk-averse investors apply to is the ratio between returns and risk. Aversion to risk should not be understood here as a dislike sensu stricto, but rather as an expectation of higher returns for higher risk. This context gives rise to the research problem. According to the available literature, the residential real estate market is susceptible to price bubbles that can appear for a whole range of reasons. One frequently mentioned is the increased supply of money, for instance the easy access to mortgages. Easy borrowing is closely related to the availability of money (JoRDA et al. 2013, p.25). For the sake of illustration, the 2010-2014 boom in the US stock market is attributed to easier access to cash stimulated by the purchases of debt instruments (known as quantitative easing) by the Fed, the Bank of Japan, the Swiss National Bank, and the European (Central Bank OLSEN 2014). A similar mechanism has also been observed in the residential real estate market. A correlation has been established between easier access to mortgage loans and housing price rises, increasing the probability of price bubbles occurring (ANUNDSEN 2014). It has also been realized that the real estate market is no longer a place where people meet their housing needs, but that it has turned into a place for capital investments. This observation is not new, but researchers now perceive it as a factor of price increases. Additional demand and relatively easy access to mortgages disturb the balance in the housing market, contributing to wider swings in prices (COŞKUN 2013, p.53) and to distinct economic cycles resulting from them (ALLEN, CARLETTI 2013). A price bubble is defined as a situation in which the prices of assets rise rapidly above the assets' fundamental value and then, an equally sudden correction takes place. Apart from the aforementioned excessive supply of money resulting from the liberalization of financial markets, price bubbles in the housing market can also be caused by its inefficiencies, particularly by insufficiently fast adjustment between housing supply and the structure of demand. The behavior of investors and their herd instinct, which is inherent in all investment processes, is also of importance (ŻELAZOWSKI 2008, p.99). Against this background, the superiority of the capital market is revealed, the structure of which adjusts to investors' expectations 
much more flexibly. But even this does not protect them from price bubbles, even though they are thought to be a less common phenomenon in this market. Price swings occur in all markets, including the real estate market and the capital market (TROJANEK 2008, p.86; ŻELAZOWSKI 2008, p.99). A spectacular price bubble in the capital market that ended in a dramatic correction of prices was inflated by the strong appreciation of dotcoms in the last decade of the $20^{\text {th }}$ century. Studies show that in the bubble formation period, the fundamental valuations of dotcoms were, according to the price bubble theory, basically different from their market prices (MORRIS, ALAM 2012). The same mechanism is observed in the housing market. This similarity was realized when the expanding financial instruments market was found to induce price rises in both the housing market and the capital market (BASCO 2014). The fact that the residential real estate market and the capital market are different is of secondary importance in analyzing the causes of price bubbles. The question about which of them is better for investing one's savings still waits to be answered.

Investors perceive price fluctuations as risk, but assessing risk is not always possible. Risk assessment in the capital market is less of a problem because stock prices quoted on a regular basis and easily calculable rates of return allow for using volatility or sensitivity measures to this end. The real estate market is much more uncertain because of its interdisciplinary character and many factors that affect its condition. Uncertainty, unlike risk, is not measurable, so investors cannot exactly assess the amount uncertainty involved in their transactions. This situation is tantamount to having incomplete information or even to misinformation. Its sources should be sought in the unpredictability of players in the real estate market, the instability of real estate attributes, and the investors' emotional attitude to transactions and their objects (RADZEWICZ, WIŚNIEWSKI 2011, p. 55-56). Uncertainty draws a line between the real estate market and the capital market, which owes its transparency to the measurability of its phenomena. This fact is of a disadvantage to investors, who must consider risks related to particular types of assets before choosing a market.

The development of the residential real estate market is determined by economic and social factors. Interregional differences in real estate prices arise from the differences in incomes earned in individual regions and from the regions' social structure (ŻELAZOWSKI 2011, p.105). These factors appear to be crucial, but they are certainly not the only ones. The capital market is much more homogenous in this respect, mainly because of its supraregional character and the players interacting with each other and influencing prices at the countrywide level rather than in particular regions.

The real estate market shows substantial correlation with the state of the economy, the strength and vectors of which vary in time. Unfortunately, the real estate index is not available, and the real estate market tends to be out of step with the rest of the economy, so generally available indices of the economic cycle are useless (FORYś 2012, p.42). The capital market is also strongly dependent on the state of the economy (it is sometimes referred to as "the barometer of economic sentiments"), but it is more transparent and, most importantly, there are many indices for analyzing its condition. Its transparency, and hence higher security of investments, derives from the availability of reliable information and frequently updated price quotations (WALLACE 1996). The limited interest of investors on the demand side in residential real estate is probably due to the lack of relevant information on these assets (WOLSKI, ZAŁĘCZNA 2013, p. 63; CLAYTON et al. 2007). Compared with the capital market, residential real estate markets have distinct local characteristics which leave investors to consider which of them to choose. American studies point out that the markets may differ in risk levels, so it is not all the same where investors commit their assets (VOICU, SEILER 2013). According to Polish studies, however, local real estate markets in Poland tend to follow each another, so it is of secondary importance for domestic investors where they will place their capital (DITTMANN 2012, p. 84).

\section{Comparison of risks and rates of return between the analyzed markets}

The above points to the need for conducting a study to determine the degree to which the secondary residential real estate market and the stock market can be treated as alternative investment options. Is the risk arising from price swings or rates of returns significantly different? If so, which of the two markets is more effective.

\subsection{Methodology}

In seeking to establish which of the two markets is more secure and more stable, the means of their 
descriptive statistics were compared. The comparison involved parameters such as average quarterly rates of return, cumulative rates of return over the sample period, standard deviations, beta coefficients, and minimum and maximum rates of return for particular segments of both markets. Using one-way ANOVA tests, the probability of both samples generating the same expected values was evaluated. The data series were divided into two sets, each containing all observations covered by the database. This means that the groups differed in the length of the data series. To determine whether inter-group variances were statistically significantly equal, Levene's test was additionally applied. Because of its results, a null hypothesis stating that the sample means were equal was tested with the Welch test and the less rigorous Brown-Forsythe test. Both of them yielded the same results each time, thus they have been presented together. The one-way ANOVA and the Welch and BrownForsythe tests were used to examine the null hypothesis about equal means against an alternative hypothesis stating otherwise. With Levene's test, a null hypothesis stating that the variances were statistically significantly different was tested against an alternative hypothesis predicting their equality. The tests were run using the SPSS software package.

\subsection{Data}

The data underpinning the study were acquired from the Warsaw Stock Exchange (WSE) and the National Bank of Poland (NBP). The WSE provided values of the selected stock indices (WIG, NCINDEX, WIG20, SWIG40, MWIG80, WIG-Budownictwo, WIG-Deweloperski) and the NBP's database was the source of the hedonic price index for the secondary housing market. Cities were sampled depending on the availability of the necessary data (Białystok, Bydgoszcz, Tricity, Katowice, Kielce, Kraków, Lublin, Łódź, Olsztyn, Opole, Poznań, Rzeszów, Szczecin, Warszawa, Wrocław, Zielona Góra). The data spanned the whole period for which housing prices were available in the database. As a result of calculations, quarterly rates of return between Q1 of 2007 and Q3 of 2014 amounting to 31 observations were obtained for all assets excluding NCINDEX and WIGDeweloperski. In the case of the last two indices, the information contained in the database allowed for calculating 28 rates of return (from Q4 of 2007) and 29 observations (from Q3 of 2007), respectively. The percentage rates of return were used as inputs in further analysis. The data were also employed to estimate the rates of return, assuming that an investment was made in the first period of analysis and realized in the last period.

\subsection{Research results}

The next stages of analysis revealed differences between the markets under consideration. First, the mean quarterly rates of return were subjected to analysis. Its results were insufficient to confirm the research hypothesis, but they highlighted where the markets differed. One-way ANOVA rejected the null hypothesis about equal means, meaning that the markets were distinct from each other. The means turned out to be different in all of the analyzed cases.

Table 1

Results of one-way ANOVA for quarterly rates of returns

\begin{tabular}{|c|c|c|c|c|c|c|c|c|}
\hline WIG & F-Stat & NCINDEX F-Stat & & WIG20 & F-Stat & & MWIG40 & F-Stat \\
\hline Bialystok & 0.002 & Bialystok & 0.884 & Bialystok & & 0.401 & Bialystok & 0 \\
\hline Bydgoszcz & 0.028 & Bydgoszcz & 0.863 & Bydgoszcz & & 0.567 & Bydgoszcz & 0.014 \\
\hline Tricity & 0.066 & Tricity & 0.932 & Tricity & & 0.1 & Tricity & 0.055 \\
\hline Katowice & 0.249 & Katowice & 0.781 & Katowice & & 0.89 & Katowice & 0.181 \\
\hline Kielce & 0.033 & Kielce & 0.862 & Kielce & & 0.621 & Kielce & 0.016 \\
\hline Krakow & 0.182 & Krakow & 0.961 & Krakow & & 0.015 & Krakow & 0.142 \\
\hline Lublin & 0.061 & Lublin & 0.852 & Lublin & & 0.752 & Lublin & 0.033 \\
\hline Lodz & 0.033 & Lodz & 0.856 & Lodz & & 0.495 & Lodz & 0.018 \\
\hline Olsztyn & 0.051 & Olsztyn & 0.926 & Olsztyn & & 0.142 & Olsztyn & 0.043 \\
\hline Opole & 0.002 & Opole & 0.896 & Opole & & 0.238 & Opole & 0.003 \\
\hline Poznan & 0 & Poznan & 0.886 & Poznan & & 0.296 & Poznan & 0 \\
\hline Rzeszow & 0.036 & Rzeszow & 0.861 & Rzeszow & & 0.664 & Rzeszow & 0.018 \\
\hline
\end{tabular}




\begin{tabular}{|c|c|c|c|c|c|c|c|}
\hline Szczecin & 0.006 & Szczecin & 0.903 & Szczecin & 0.244 & Szczecin & 0.007 \\
\hline Warszawa & 0.089 & Warszawa & 0.937 & Warszawa & 0.091 & Warszawa & 0.071 \\
\hline Wroclaw & 0.152 & Wroclaw & 0.953 & Wroclaw & 0.031 & Wroclaw & 0.118 \\
\hline Zielona & & Zielona & & Zielona & & Zielona & \\
\hline Gora & 0 & Gora & 0.886 & Gora & 0.312 & Gora & 0 \\
\hline
\end{tabular}

Table 1 cont.

\begin{tabular}{|c|c|c|c|c|c|}
\hline SWIG80 & F-Stat & $\begin{array}{l}\text { WIG- } \\
\text { Budownictwo }\end{array}$ & F-Stat & $\begin{array}{l}\text { WIG- } \\
\text { Deweloperski }\end{array}$ & F-Stat \\
\hline Bialystok & 0 & Bialystok & 1.315 & Bialystok & 1.926 \\
\hline Bydgoszcz & 0.007 & Bydgoszcz & 1.509 & Bydgoszcz & 2.131 \\
\hline Tricity & 0.066 & Tricity & 0.862 & Tricity & 1.417 \\
\hline Katowice & 0.155 & Katowice & 1.803 & Katowice & 2.352 \\
\hline Kielce & 0.009 & Kielce & 1.577 & Kielce & 2.214 \\
\hline Krakow & 0.155 & Krakow & 0.625 & Krakow & 1.129 \\
\hline Lublin & 0.021 & Lublin & 1.72 & Lublin & 2.371 \\
\hline Lodz & 0.011 & Lodz & 1.392 & Lodz & 1.97 \\
\hline Olsztyn & 0.054 & Olsztyn & 0.961 & Olsztyn & 1.543 \\
\hline Opole & 0.007 & Opole & 1.053 & Opole & 1.604 \\
\hline Poznan & 0.001 & Poznan & 1.138 & Poznan & 1.699 \\
\hline Rzeszow & 0.01 & Rzeszow & 1.628 & Rzeszow & 2.276 \\
\hline Szczecin & 0.012 & Szczecin & 1.094 & Szczecin & 1.674 \\
\hline Warszawa & 0.083 & Warszawa & 0.868 & Warszawa & 1.437 \\
\hline Wroclaw & 0.131 & Wroclaw & 0.698 & Wroclaw & 1.225 \\
\hline $\begin{array}{l}\text { Zielona } \\
\text { Gora }\end{array}$ & 0.001 & Zielona Gora & 1.169 & Zielona Gora & 1.74 \\
\hline
\end{tabular}

* Significance level of 0.05 .

Source: developed by the author.

To validate the results, variances were tested for equality. If the equality condition had not been met or the data series for both markets had been found to differ in length, more tests would have been necessary. The null hypothesis about unequal variances was rejected each time the rate-of-return series for the capital market and the housing market in Katowice were analyzed. It was rejected again when the series of average rates of return from the WIG index and from the residential real estate market in Opole were examined. Because of the common presence of unequal variances, the author decided to run the Welch and Brown-Forsythe tests.

Table 2

The results of Levene's variance homogeneity test for quarterly rates of returns

\begin{tabular}{|c|c|c|c|c|c|c|c|}
\hline WIG & W & NCINDEX W & & WIG20 & W & MWIG40 & W \\
\hline Bialystok & $13.463^{*}$ & Bialystok & $4.5^{*}$ & Bialystok & $10.119^{*}$ & Bialystok & $17.282^{*}$ \\
\hline Bydgoszcz & $11.034^{*}$ & Bydgoszcz & $4.446^{*}$ & Bydgoszcz & $7.956^{*}$ & Bydgoszcz & $15.03^{*}$ \\
\hline Tricity & $15.274^{*}$ & Tricity & $4.532^{*}$ & Tricity & $11.773^{*}$ & Tricity & $18.869^{*}$ \\
\hline Katowice & 0.065 & Katowice & 3.69 & Katowice & 0.063 & Katowice & 1.241 \\
\hline Kielce & $13.711^{*}$ & Kielce & $4.499 *$ & Kielce & $10.333^{*}$ & Kielce & $17.492^{*}$ \\
\hline Krakow & $12.041^{*}$ & Krakow & $4.412^{*}$ & Krakow & $8.719^{*}$ & Krakow & $15.883^{*}$ \\
\hline Lublin & $13.436^{*}$ & Lublin & $4.462^{*}$ & Lublin & $10.023^{*}$ & Lublin & $17.174^{*}$ \\
\hline
\end{tabular}




\begin{tabular}{|c|c|c|c|c|c|c|c|}
\hline Lodz & $5.727^{*}$ & Lodz & $4.317^{*}$ & Lodz & 3.633 & Lodz & $9.429^{*}$ \\
\hline Olsztyn & $23.461^{*}$ & Olsztyn & $4.71^{*}$ & Olsztyn & $19.722^{*}$ & Olsztyn & $25.747^{*}$ \\
\hline Opole & 3.721 & Opole & $4.094^{*}$ & Opole & 1.786 & Opole & $7.391^{*}$ \\
\hline Poznan & $4.808^{*}$ & Poznan & $4.19^{*}$ & Poznan & 2.705 & Poznan & $8.56^{*}$ \\
\hline Rzeszow & $15.58^{*}$ & Rzeszow & $4.516^{*}$ & Rzeszow & $12.026^{*}$ & Rzeszow & $19.064^{*}$ \\
\hline Szczecin & $11.582^{*}$ & Szczecin & $4.453^{*}$ & Szczecin & $8.424^{*}$ & Szczecin & $15.543^{*}$ \\
\hline Warszawa & $25.189^{*}$ & Warszawa & $4.734^{*}$ & Warszawa & $21.46^{*}$ & Warszawa & $27.073^{*}$ \\
\hline Wroclaw & $16.84^{*}$ & Wroclaw & $4.565^{*}$ & Wroclaw & $13.248^{*}$ & Wroclaw & $20.221^{*}$ \\
\hline Zielona & & Zielona & & Zielona & & Zielona & \\
\hline Gora & $4.876^{*}$ & Gora & $4.162^{*}$ & Gora & 2.664 & Gora & $8.714^{*}$ \\
\hline
\end{tabular}

Table 2 cont.

\begin{tabular}{lrlrlr}
\hline SWIG80 & W & \multicolumn{2}{l}{$\begin{array}{l}\text { WIG- } \\
\text { Budownictwo }\end{array}$} & \multicolumn{2}{c}{$\begin{array}{l}\text { WIG- } \\
\text { deweloperski }\end{array}$} \\
\hline Bialystok & $19.838^{*}$ & Bialystok & $17.11^{*}$ & Bialystok & $15.458^{*}$ \\
\hline Bydgoszcz & $17.37^{*}$ & Bydgoszcz & $15.13^{*}$ & Bydgoszcz & $13.86^{*}$ \\
\hline Tricity & $21.578^{*}$ & Tricity & $18.476^{*}$ & Tricity & $16.539^{*}$ \\
\hline Katowice & 1.84 & Katowice & 1.779 & Katowice & 2.124 \\
\hline Kielce & $20.079^{*}$ & Kielce & $17.279^{*}$ & Kielce & $15.58^{*}$ \\
\hline Krakow & $18.418^{*}$ & Krakow & $15.757^{*}$ & Krakow & $14.255^{*}$ \\
\hline Lublin & $19.791^{*}$ & Lublin & $16.928^{*}$ & Lublin & $15.235^{*}$ \\
\hline Lodz & $11.104^{*}$ & Lodz & $10.053^{*}$ & Lodz & $9.675^{*}$ \\
\hline Olsztyn & $28.938^{*}$ Olsztyn & $24.444^{*}$ & Olsztyn & $21.331^{*}$ \\
\hline Opole & $9.083^{*}$ Opole & $8.019^{*}$ & Opole & $7.792^{*}$ \\
\hline Poznan & $10.301^{*}$ & Poznan & $9.161^{*}$ & Poznan & $8.818^{*}$ \\
\hline Rzeszow & $21.83^{*}$ & Rzeszow & $18.586^{*}$ & Rzeszow & $16.578^{*}$ \\
\hline Szczecin & $17.945^{*}$ & Szczecin & $15.572^{*}$ & Szczecin & $14.207^{*}$ \\
\hline Warszawa & $30.363^{*}$ & Warszawa & $25.55^{*}$ & Warszawa & $22.188^{*}$ \\
\hline Wroclaw & $23.038^{*}$ & Wroclaw & $19.648^{*}$ & Wroclaw & $17.478^{*}$ \\
\hline Zielona & & & & & \\
Gora & $10.542^{*}$ Zielona Gora & $9.27^{*}$ Zielona Gora & $8.872^{*}$ \\
\hline
\end{tabular}

* Significance level 0.05 .

Source: developed by the author.

The tests confirmed the results obtained from one-way ANOVA. The hypothesis about equal means was rejected in each case, meaning that the analyzed markets yielded different rates of return.

Table 3

Robust Welch and Brown-Forsythe tests of equality of means for quarterly rates of returns

\begin{tabular}{lrlrlrrr}
\hline WIG & F-Stat & NCINDEX & F-Stat & & WIG20 & F-Stat & \multicolumn{2}{c}{ MWIG40 } & \multicolumn{1}{l}{ F-Stat } \\
\hline Bialystok & 0.002 & Bialystok & 0.797 & Bialystok & 0.401 & Bialystok & 0 \\
\hline Bydgoszcz & 0.028 & Bydgoszcz & 0.778 & Bydgoszcz & 0.567 & Bydgoszcz & 0.014 \\
\hline Tricity & 0.066 & Tricity & 0.841 & Tricity & 0.1 Tricity & 0.055 \\
\hline Katowice & 0.249 & Katowice & 0.705 & Katowice & 0.89 & Katowice & 0.181 \\
\hline Kielce & 0.033 & Kielce & 0.777 & Kielce & 0.621 & Kielce & 0.016 \\
\hline Krakow & 0.182 & Krakow & 0.866 & Krakow & 0.015 & Krakow & 0.142 \\
\hline Lublin & 0.061 & Lublin & 0.768 Lublin & 0.752 & Lublin & 0.033 \\
\hline
\end{tabular}




\begin{tabular}{|c|c|c|c|c|c|c|c|}
\hline Lodz & 0.033 & Lodz & 0.772 & Lodz & 0.495 & Lodz & 0.018 \\
\hline Olsztyn & 0.051 & Olsztyn & 0.835 & Olsztyn & 0.142 & Olsztyn & 0.043 \\
\hline Opole & 0.002 & Opole & 0.808 & Opole & 0.238 & Opole & 0.003 \\
\hline Poznan & 0 & Poznan & 0.8 & Poznan & 0.296 & Poznan & 0 \\
\hline Rzeszow & 0.036 & Rzeszow & 0.777 & Rzeszow & 0.664 & Rzeszow & 0.018 \\
\hline Szczecin & 0.006 & Szczecin & 0.814 & Szczecin & 0.244 & Szczecin & 0.007 \\
\hline Warszawa & 0.089 & Warszawa & 0.845 & Warszawa & 0.091 & Warszawa & 0.071 \\
\hline Wroclaw & 0.152 & Wroclaw & 0.86 & Wroclaw & 0.031 & Wroclaw & 0.118 \\
\hline Zielona & & Zielona & & Zielona & & Zielona & \\
\hline Gora & 0 & Gora & 0.8 & Gora & 0.312 & Gora & 0 \\
\hline
\end{tabular}

Table 3 cont.

\begin{tabular}{|c|c|c|c|c|c|}
\hline SWIG80 & F-Stat & $\begin{array}{l}\text { WIG- } \\
\text { Budownictwo }\end{array}$ & F-Stat & $\begin{array}{l}\text { WIG- } \\
\text { deweloperski }\end{array}$ & F-Stat \\
\hline Bialystok & 0 & Bialystok & 1.315 & Bialystok & 1.822 \\
\hline Bydgoszcz & 0.007 & Bydgoszcz & 1.509 & Bydgoszcz & 2.022 \\
\hline Tricity & 0.066 & Tricity & 0.862 & Tricity & 1.338 \\
\hline Katowice & 0.155 & Katowice & 1.803 & Katowice & 2.304 \\
\hline Kielce & 0.009 & Kielce & 1.577 & Kielce & 2.093 \\
\hline Krakow & 0.155 & Krakow & 0.625 & Krakow & 1.067 \\
\hline Lublin & 0.021 & Lublin & 1.72 & Lublin & 2.239 \\
\hline Lodz & 0.011 & Lodz & 1.392 & Lodz & 1.891 \\
\hline Olsztyn & 0.054 & Olsztyn & 0.961 & Olsztyn & 1.45 \\
\hline Opole & 0.007 & Opole & 1.053 & Opole & 1.534 \\
\hline Poznan & 0.001 & Poznan & 1.138 & Poznan & 1.625 \\
\hline Rzeszow & 0.01 & Rzeszow & 1.628 & Rzeszow & 2.146 \\
\hline Szczecin & 0.012 & Szczecin & 1.094 & Szczecin & 1.587 \\
\hline Warszawa & 0.083 & Warszawa & 0.868 & Warszawa & 1.349 \\
\hline Wroclaw & 0.131 & Wroclaw & 0.698 & Wroclaw & 1.155 \\
\hline $\begin{array}{l}\text { Zielona } \\
\text { Gora }\end{array}$ & 0.001 & Zielona Gora & 1.169 & Zielona Gora & 1.66 \\
\hline
\end{tabular}

** Asymptotically distributed $F$.

* Significance level of 0.05 .

$$
\text { Source: developed by the author. }
$$

The results obtained thus far pointed to differences between both investigated markets. Five descriptive statistics were calculated for each of them, as well as the rate of return showing investment efficiency in the whole analyzed period, assuming that it was made in the first quarter of 2007 (or later for NCINDEX and WIG-Deweloperski) and realized in the last quarter of the analysis (the third quarter of 2014). The standard deviation and beta coefficient were calculated for the whole available period, and the minimum and maximum quarterly rates of return for particular segments of the markets. The author believed that calculating the beta coefficient for the real estate market was of doubtful use, but decided to do so to enable comparisons WOLSKI (2014). The means of descriptive statistics were derived from the statistics calculated for the individual indices and cities. In this way, the tested observations were divided between the stock market and the secondary housing market. The results of these tests have been presented in Table 4 .

Data series made up of the descriptive statistics of successive indices and of successive local housing markets were subjected to analysis to see if the means for the capital market and the housing market were equal 
Table 4

Means of descriptive statistics for capital and real-estate markets

\begin{tabular}{lcc}
\hline & $\begin{array}{l}\text { Share } \\
\text { market }\end{array}$ & $\begin{array}{l}\text { Secondary real- } \\
\text { estate housing } \\
\text { market }\end{array}$ \\
\hline Cumulated rate of return & 0.075 & 0.296 \\
\hline Beta coefficient & 1.000 & 0.070 \\
\hline Standard deviation & 0.350 & 0.065 \\
\hline $\begin{array}{l}\text { Minimum quarterly rate of } \\
\text { return }\end{array}$ & -0.340 & -0.096 \\
\hline $\begin{array}{l}\text { Maximum quarterly rate of } \\
\text { return }\end{array}$ & 1.451 & 0.230 \\
\hline
\end{tabular}

Source: developed by the author.

Table 5

Results of one-way ANOVA, Levene's variance homogeneity test and robust Welch and Brown-

Forsythe tests of the equality of means of descriptive statistics

\begin{tabular}{lrrrrrrr}
\hline & \multicolumn{2}{c}{$\begin{array}{l}\text { One-way } \\
\text { ANOVA F-Stat }\end{array}$} & \multicolumn{1}{l}{ Sig. } & \multicolumn{2}{c}{ Levene's W } & Sig. & \multicolumn{2}{l}{$\begin{array}{l}\text { Welch and Brown- } \\
\text { Forsythe F-Stat }\end{array}$} \\
\hline Cumulated R & 0.732 & 0.402 & $5.189^{*}$ & 0.033 & 0.331 & 0.585 \\
\hline Beta coef. & $169.015^{*}$ & 0 & $6.134^{*}$ & 0.022 & $88.341^{*}$ & 0 \\
\hline Standard dev. & $4.78^{*}$ & 0.04 & $12.527^{*}$ & 0.002 & 1.972 & 0.21 \\
\hline Minimum q.R & $93.398^{*}$ & 0 & $7.198^{*}$ & 0.014 & $60.078^{*}$ & 0 \\
\hline $\begin{array}{l}\text { Maximum } \\
\text { q.R }\end{array}$ & 2.845 & 0.106 & $12.77^{*}$ & 0.002 & 1.172 & 0.321 \\
\hline
\end{tabular}

** Asymptotically distributed F.

* Significance level of 0.05 .

Source: developed by the author.

In two aspects that are important for the purpose of this article, i.e. the cumulative rate of return and standard deviation, the analysis failed to prove the equality of means. The alternative hypothesis that means were not equal was also confirmed in the case of the maximum quarterly rates of return. The hypothesis about equal means was not rejected for the beta coefficient and the quarterly minimum rates of return.

Figure 1 provides a graphic summary of the results of the study. The real estate market shows lower risk measured by standard deviation and, somewhat surprisingly, a higher cumulative rate of return. Statistically significant differences in the beta coefficient were not found, although the graph seems to point to major discrepancies in its values. It must be borne in mind, however, that the applicability of this coefficient to the real estate market is disputable (see above). The results of the analysis confirmed the research hypothesis. Investors wishing to use its outcomes to choose a type of investment must be cautioned, however, that they may have been distorted by substantial uncertainty involved in the real-estate market (RADZIEWICZ, WIŚNIEWSKI 2011).

\section{Conclusions}

The residential real estate market and the capital market are basically different from each other, but they are also similar in many ways. These similarities lead to the necessity of investors considering which of the markets is more appropriate for their purposes. It is important that the decision-making process includes an in-depth analysis of the differences between the two markets. The differences generate risk factors and thus, influence the investors' sense of security, the ease of getting information, the liquidity of the market-quoted assets, the capital intensity of investments, and the relationship between the rates of return and local circumstances. The decision that is ultimately reached by an investor therefore depends on the results of the investigation into the investment environment. Because the real estate market has many inconveniences, investors may want to weigh 
whether to commit their resources to the capital market commonly perceived as riskier, or to seek shelter in the safer real estate market. In the present article, the markets were compared to determine which of them was more profitable and less risky. To evaluate the research hypothesis, a number of tests seeking to establish whether the markets' average rates of return and risk measures were different or equal were conducted. The analysis found differences between the secondary housing market and the stock market with respect to their cumulative average rates of return and standard deviations. In the first of the markets they were, respectively, higher and lower than in the latter market, thus the research hypothesis was confirmed. Investments in the secondary housing market proved less risky but also, contrary to expectations, more profitable.
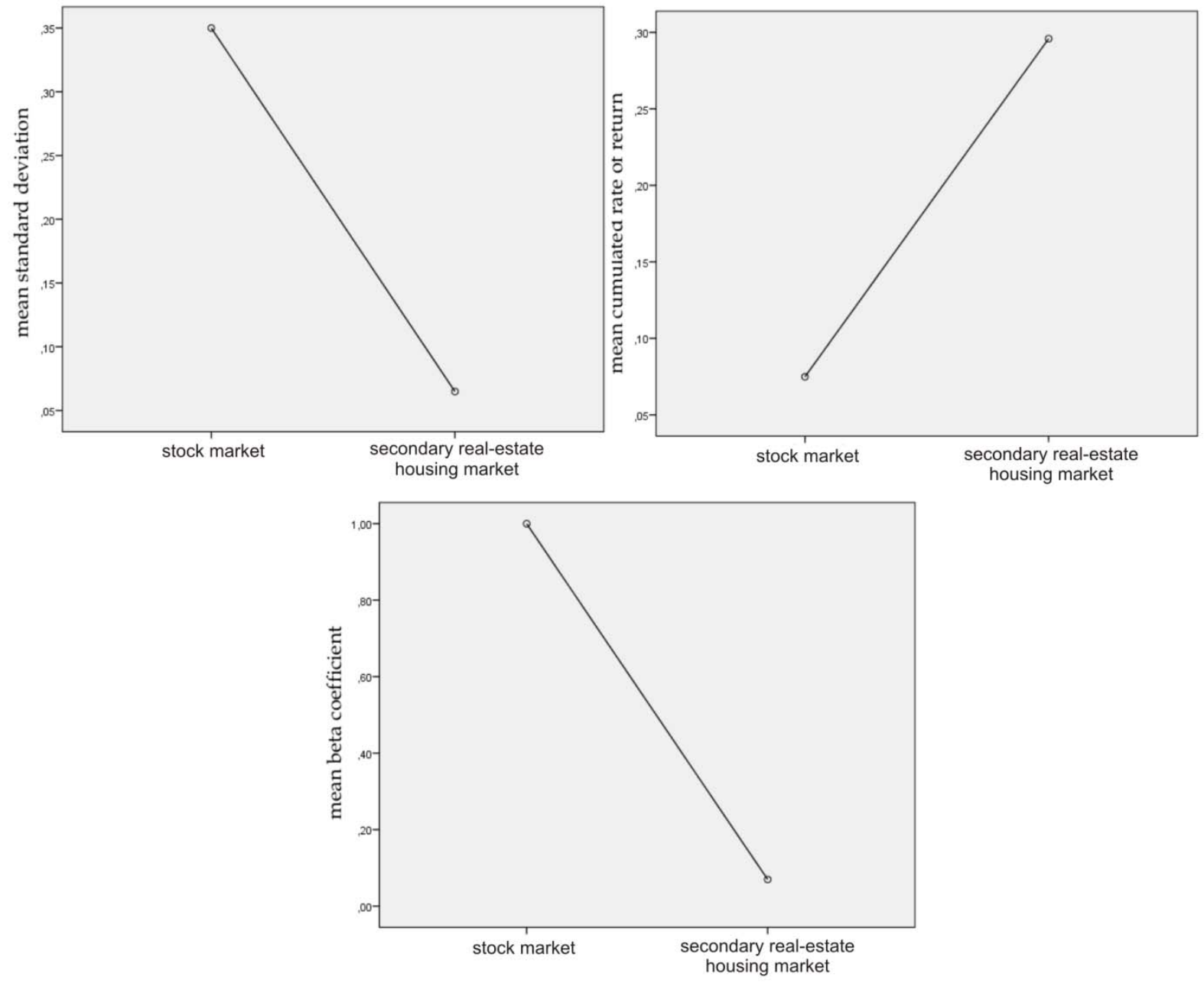

Fig. 1. Mean standard deviation, beta coefficients and rates of return for the stock market and the secondary housing market. Source: developed by the author, SPSS software.

\section{References}

Allen, F., CARletti, E., 2013, Systemic Risk from Real Estate and Macro-Prudential Regulation, International Journal of Banking, Accounting and Finance Vol. 5, No. 1, pp. 28-48.

Anundsen, A., Gerdrup K., HANSENy F., Kragh-Sørensen K., 2014, Bubbles and Crises: The Role of House Prices and Credit, Norges Bank: Working Papers [serial online], November 21, (14).

BASCO, S., 2014, Globalization and Financial Development: A Model of the Dot-Com and the Housing Bubbles, Journal of International Economics, 92, 1, Jan., pp. 78-94.

Clayton, J., Gordon, J., N., FAbOZZi, J., F., GiliberTo, S., M., LiAnG, Y., HudsOn-Wilson, S., 2007, Real Estate Comes of Age, The Journal of Portfolio Management, Vol. 33, No. 5, DOI: 10.3905/jpm.2007.698955, pp. 15-26.

COŞKUN, Y., 2013, Housing-Construction Market Risks in Turkey: Overrated or Underestimated?, Housing Finance International, Spring, 27(3), pp. 46-54.

DĘBSKI, W., 2010, Rynek finansowy i jego mechanizmy. Podstawy teorii i praktyki, (Financial Maret and its 
Mechanisms. Basics of Theory and Practise), Wydawnictwo Naukowe PWN (Polish Scientific Publishers PWN), Warsaw.

DitTMANN, I., 2012, Lokalne rynki mieszkaniowe w Polsce-podobieństwo pod względem zmian cen transakcyjnych oraz dostęności mieszkań, (Local Residential Markets in Poland - Similarity in Terms of Changes in Transaction Prices and Availability), red. nauk. Źróbek, S., Studia i Materiały Towarzystwa Naukowego Nieruchomości (Journal of the Polish Real Estate Scientific Society), Vol. 20, No. 1, TNN, Olsztyn, pp. 71-90.

DusANSKY, R., KOÇ, Ç., ONUR, I., 2012, Household Housing Demand: Empirical Analysis and Theoretical Reconciliation, Journal Of Real Estate Finance \& Economics, May, 44(4), pp. 429-445.

FORYŚ, I., 2012, Metoda mix-adjustment wyznaczania indeksów cen nieruchomości mieszkaniowych na przykładzie lokali spótdzielczych, (Mix-Adjustment Method Used to Construct Residential House Price Indices on the Example of Cooperative Housing), red. nauk. Źróbek, S., Studia i Materiały Towarzystwa Naukowego Nieruchomości (Journal of the Polish Real Estate Scientific Society), Vol. 20, No. 1, TNN, Olsztyn, pp. 41-52.

JordA, O., SCHLURARICK, M., TAYLOR, A., 2013, When Credit Bites Back, Journal Of Money, Credit \& Banking (Wiley-Blackwell), December 2, pp. 3-28.

KUCHARSKA - STASIAK, E., 2006, Nieruchomość w gospodarce rynkowej, (Real estate in a market economy), PWN, Warsaw.

MorRis, J., Alam, P., 2012, Value Relevance and the Dot-com Bubble of the 1990s, Quarterly Review of Economics \& Finance, May, 52(2), pp. 243-255.

OlsEN, J., 2014, The Impact of Quantitative Easing on Equity Prices, Journal Of Financial Planning, May, 27(5), pp. 52-60.

RADZEWICZ, A., WIŚNIEWSKI, R., 2011, Niepewność rynku nieruchomości, (Uncertainty of the Real Estate Market), Studia i Materiały Towarzystwa Naukowego Nieruchomości, Vol. 19, No. 1, TNN, Olsztyn pp. 47-59.

STRĄCZKOWSKI, Ł., 2009, Motywy zakupu mieszkań w świetle badań nabywców na lokalnym rynku mieszkaniowym w Poznaniu, (Motives Behind the Purchase of Flats in Light of Research on Buyers on a Local Housing Market in Poznan), Studia i Materiały Towarzystwa Naukowego Nieruchomości (Journal of the Polish Real Estate Scientific Society), Vol. 17, No. 2, TNN, Olsztyn, pp. 45-56.

TROJANEK, R., 2008, Determinanty wahań cen na rynku mieszkaniowym, (Determinants of House Price Fluctuations), Studia i Materiały Towarzystwa Naukowego Nieruchomości, Vol. 16, No. 4, TNN, Olsztyn, pp. 85-97.

VOICU, C., SEILER, M. J., 2013, Understanding Systematic Risk in Real Estate Markets, Journal Of Housing Research, 22(2), pp. 165-201.

WAllace, N. E., 1996, Hedonic-Based Price Indexes for Housing: Theory, Estimation, and Index Construction, Economic Review (03630021), (3), 34, pp. 34-49.

WOLSKI, R., 2014, Application of Beta Coefficient in the Market of Direct Residential Real Estate Investments, Real Estate Management and Valuation, Vol. 22, No. 2, pp. 13-21.

Wolski, R., ZAŁĘCZNA, M., 2013, The Attractiveness of Real Estate Investment in Polish Conditions, Real Estate Management and Valuation. Vol. 21, Issue 3, October, ISSN (Online) 1733-2478, DOI: 10.2478/remav-2013-0027, pp. 62-70.

ŻELAZOWSKI, K., 2008, Zjawisko baniek cenowych na rynkach nieruchomości (Price Bubbles on Real Estate Markets), Studia i Materiały Towarzystwa Naukowego Nieruchomości (Journal of the Polish Real Estate Scientific Society), Vol. 16, No. 4, TNN, Olsztyn, pp. 99-108.

ŻELAZOWSKI, K., 2011, Regionalne zróżnicowanie cen i ich determinant na rynku mieszkaniowym w Polsce, (Regional Differences in Prices and Their Determinants on Polish Housing Market), red. nauk. Źróbek, S., Studia i Materiały Towarzystwa Naukowego Nieruchomości (Journal of the Polish Real Estate Scientific Society), Vol. 19, No. 3, TNN, Olsztyn, pp. 98-106. 